\section{Maruša Šegec}

Osnovna šola Vojke Šmuc Izola

marusa.segec@osvsmuc.si
Zbornik povzetkov strokovne konference Spodbujanje učinkovitega učenja, Koper, 26. avgust 2020

Abstracts of the Professional Conference Developing Effective Learning, Koper, 26 August 2020

\section{Spremembe so stalnica našega življenja}

Učence, ki trenutno obiskujejo osnovno šolo, imenujemo »generacija Z«, za katero je značilno, da kliče po spremembah in se jim hitro prilagaja ter da dobro samostojno rokuje s tehnologijo. Vloga njenih pripadnikov v procesu učenja se $v$ zadnjem času korenito spreminja. Pouk je vedno bolj usmerjen v učenca, saj ta pridobiva glavno vlogo, učitelj pa prevzema vlogo usmerjevalca. Na učenca osredinjen pouk zahteva fleksibilnega učitelja, saj mora med nenehnimi spremembami pri učencih, učnih načrtih, kriterijih, dejavnostih, dogodkih $v$ svetu in $v$ okolju uspešno krmariti. Poskrbeti mora tudi za dobre medsebojne odnose med učenci ter učenci in učitelji, posebno pozornost pa mora nameniti motivaciji učencev za delo $v$ šoli. Učitelj učencem motivacijo največkrat poveča z gibalnodidaktično igro ob glasbi ali s frontalno razlago učne snovi, ki temelji na metodi »eight minute teacher«, to je nekajminutna razlaga novih učnih vsebin, ki vzbudi radovednost in spodbuja aktivno izobraževalno okolje in medvrstniško sodelovanje. Učenci si po predstavitvi ciljev in dejavnosti izberejo skupino sošolcev ali posameznega sošolca za delo ter šolski prostor, kjer se bodo učili ali reševali načrtovane dejavnosti. Po korakih formativnega spremljanja se ves čas vrstijo medvrstniške ali učiteljeve povratne informacije, ki niso dokončne sodbe o znanju, ampak vodila za izboljšave. Med procesom učenja se oblikujejo kriteriji odličnosti, zato šola ni več zgolj prostor, kjer se le posluša in zapisuje, temveč prostor, kjer se učenci aktivno učijo in imajo nadzor nad svojim znanjem, zato končna ocena ni presenečenje za nikogar.

Ključne besede: aktivne oblike pouka, nova vloga učenca in učitelja, šola - prostor za učenje

\section{Changes Represent a Constant Part of Our Lives}

Students who are currently enrolled in school are commonly known as 'Generation Z.' They were born in an era of great technological advancement which affects their mind functioning. Thus it is of great importance that the educational system adapts to their needs and responds to the fact that students' role in the process of learning has been changed to a large extent. The teacher has to be flexible in order to ensure that he/she is capable of successfully navigating constant changes of activities, criteria, students, teaching plans, etc. The teacher is also responsible for ensuring that the relationships within the classroom are positive and that students are highly motivated and eager to learn. Some methods that can be used to stimulate a high level of motivation are the use of motor-didactic play with music and frontal explanation of the school topic that is based on the method called 'eight-minute teacher.' The method consists of a short lecture that ensures curiosity and promotes an active learning environment and cooperation among students. After goals and activities have been presented, students choose their study group or a peer to work with as well as the space for studying or doing certain activities. According to the formative assessment concept, peer and teacher feedback are given, which are not meant to be the final assessment but serve to provide guidelines for improvement. Criteria of excellence are being formulated in the process of learning, so school is no longer just an institution where students listen and take notes, but instead they participate in an environment of active learning, where each student can control his or her knowledge, thus the final grade is no longer a surprise.

Key words: active teaching, the changed student's and teacher's role, schoollearning environment 